Governments generally favor differentiation because it promises cost containment and a coherent strategy for building high-quality institutions. But clearly the English higher education sector remains largely antagonistic to this agenda. The prospect of the fee structure alone creates great uncertainty for a majority of England's higher education institutions over what to charge. Many oppose the proposal, including a substantial and vocal portion of Blair's cabinet, some of whom have offered blustery threats of resignation if the scheme is adopted.

And in this tension lies the rub. A major and vocal opponent of the fee scheme is the chancellor of the exchequer, Gordon Brown. In the realm of parliamentary politics, Brown is an appointment of Blair's and is also a political rival with substantial powers regarding budgeting. Add to this the instability of Blair's government with the onset of war with Iraq (at least at the time of this writing) and it becomes clear that the fate of the white paper is uncertain.

\section{China's New Private Education}

\section{Law}

\section{Fengqiao Yan and Daniel C. Levy}

Fengqiao Yan is associate professor at the Graduate School of Education, Peking University, Beijing, China and a PROPHE collaborating scholar. E-mail: fayan@gse.pku.edu.cn. Daniel C. Levy is SUNY Distinguished Professor, State University of New York at Albany, and PROPHE director. E-mail: Dlevy@uamail.albany.edu.

IHE devotes a column in each issue to a contribution from PROPHE, the Program for Research on Private Higher Education, headquartered at the University at Albany. PROPHE and the CIHE are partners in a cooperative effort supported by the Ford Foundation to build and disseminate information about private higher education globally. See http:// www.albany.edu/ prophe.

$T^{2}$ he private education law, promulgated on December 28, 2002, is China's first national legislation on private education. The law covers all educational levels, although we are focusing on the three articles $(16,53$, and 55) that cover higher education. The law's main thrust concerning higher education is to provide a legal framework to facilitate private growth and initiate a longer process to accredit, merge, dismantle, and change institutions at that level.

Notwithstanding the centralism of Chinese national politics, the evolution of this law has been remarkably meandering. As opposed to having a clear blueprint from which to work, the government has generally reacted to society- and market-driven growth. Private higher education has emerged and evolved in the absence of a clear legal framework. However startling this development may seem for China, the phenomenon of the rapid expansion of private higher education, followed by a delay in establishing a legal framework, has become a common occurrence internationally in recent decades.

China's initial legal recognition of private education, in the 1982 constitution, was vague in encouraging not just state but "other entities." Though private education was allowed for the first time in 30 years, the constitution left it vulnerable to ambiguities and threats. This contributed to bureaucratic misconduct, lawsuits, and a yearning for greater clarity or support. For example, private institutions have complained that government agencies are levying fees arbitrarily. Students have been demanding the same discounts in transportation fares that their public counterparts receive and reimbursement of tuition fees if their institutions go bankrupt.

Debate over the proposed law was vigorous, pitting proponents of private higher education against opponents of the private sector. In a scenario seen elsewhere in the developing world, the growth of the private sector involves colleges that are seen as academically inferior to the public universities clashing with the established traditions and standards of the public universities. Private institutions are criticized for focusing on profits and showing little concern for quality. Arguments in support of the private sector center on economic freedom, property rights, competition, choice, and access.

Government positions have varied within different local, provincial, and national contexts. The generally supportive national posture toward privatization stems from the belief that China needs to expand enrollments rapidly yet not at public expense-a common reason for government support of private growth in Asia and beyond.

China's private sector is both decentralized and localized. When China adopted its higher education expansion policy in 1999, the central government delegated the accrediting authority of non-degree-granting institutions to the provincial governments. This change has helped to elevate many institutions that previously provided only "self-study programs" to prepare students for the national examinations. These programs are situated outside the category of accredited degree programs.

As of 2002, only 4 private colleges had been authorized to award the bachelor's degree and 129 a "sub-bachelor's" degree. The more than 1,200 other private colleges lacked official government authorization and were only allowed to offer self-study programs. All told, the private sector 
accounts for 10 percent of China's higher education enrollments.

Within the private sector, the legal distinction between for-profit and nonprofit education is neither clear-cut nor consistent. The 1995 education law regarded education as a nonprofit enterprise. However, in reality private institutions registered with the Industry and Commerce Bureau have been allowed to make a profit and need to pay taxes. These for-profits usually provide short-term training programs-such as instruction in foreign languages-but cannot offer degrees. Private institutions registered with the Bureau of Civil Administration are nonprofit and largely tax exempt. But even in nonprofits, investors and managers expect an economic return on their investment and efforts. A vital feature of the 2002 law, which focuses on the nonprofits, is article 51's clause that grants permission for "reasonable economic return from net income after deducting costs, development funds, and other items stipulated by the government." The law calls such returns a governmental reward rather than a profit. These provisions mark a compromise on a hotly debated issue. The Ministry of Education is considering the complex matter of how to determine what represents a reasonable economic return. Another provision of the 2002 law gives individuals and corporate entities favorable tax treatment if they donate to private institutions (article 47).

The legal challenges concerning nonprofit and forprofit institutions relate to the way Chinese private education today differs from its pre-1949 predecessor. Back then, most private colleges were church-affiliated or supported by philanthropy, and the owners were dedicated to pursuing religious beliefs or other educational or social missions. In contrast, most owners of private colleges today seek to maximize revenues. In its shift from a more values-oriented to a commercially driven higher education system, Chinese private higher education fits into a global trend.

Since the 1982 constitution, several official documents have furthered the promotion of private education. In 1993, the Communist Party and the government became more explicit in encouraging, supporting, directing, and regulating private education. In 1997 the government issued the first regulations concerning private education, which reaffirmed private education's nonprofit nature. However, the 1997 regulations gave the priority to levels other than higher education (e.g., vocational, adult, and preschool), and the national government, concerned about quality, reiterated strict standards and procedures for the establishment of private colleges.

The 2002 law thus is part of the ongoing struggle to come to grips with the legal issues concerning private higher education in its current state and in the future. The law takes a position on several ambiguous and controversial issues such as finance, the relative status of public and private institutions, tax policy, economic return, and property rights-although the State Council still must determine specific regulations and might devolve further authority to the provincial governments. A separate regulation (March 1, 2003), also mostly intended to promote the private sector, concerns schools jointly invested in and run with foreign partner institutions. Yet other sensitive issues remain unresolved, such as the status of public-private hybrids.

Understandably, implementation of a far-reaching and sometimes ambiguous law is often even harder and more complex to implement than the mere formulation of the law. In any event, the 2002 law is a double-edged sword, aiming both to promote and regulate private

\section{The International Role of U.S. Recognized Accrediting Organizations \\ Judith S. Eaton}

Judith S. Eaton is president of the Council for Higher Education Accreditation. Address: One Dupont Circle, \#510, Washington, DC 20036.

E-mail: eaton@chea.org. Website: www.chea.org.

$\mathrm{I}_{\mathrm{t}}^{\mathrm{n}}$ n fall 2001, the Council for Higher Education Accredi1 tation (CHEA) surveyed the 78 institutional (regional and national) and programmatic accreditors in the United States that are recognized by the CHEA and U.S. Department of Education. The purpose of the survey was to learn whether and to what extent these accreditors operate internationally.

\section{General Findings}

The 53 accreditors who responded to the 2001 survey included 5 national accreditors, 6 regional accreditors, and 42 specialized/professional accrediting organizations. Twenty-nine of the organizations (62.9 percent) indicated that they were operating internationally. This included all 5 (100 percent) of the responding national accreditors, all 6 (100 percent) of the responding regional accreditors, and 18 of the 42 (42.8 percent) responding specialized accreditors.

These 29 organizations were accrediting 461 institutions and programs in 65 countries outside the United States as of fall 2001. They also accredit 9 nonU.S. institutions operating within the United States. Two of the 53 organizations have separate standards for accrediting internationally. 